\title{
TITLE:
}

\section{$<$ Note $>$ Well Digging by Semliki Chimpanzees: New Data on Laterality and Possible Significance of Hydrology}

\section{$\operatorname{AUTHOR}(S)$ :}

McGrew, William C.; Marchant, Linda F.; Payne, Charlotte L.R.; Webster, Timothy H.; Hunt, Kevin D.

\section{CITATION:}

McGrew, William C....[et al]. < Note> Well Digging by Semliki Chimpanzees: New Data on Laterality and Possible Significance of Hydrology. Pan Africa News 2013, 20(1): 5-8

\section{ISSUE DATE:}

2013-06

URL:

http://hdl.handle.net/2433/177625

RIGHT:

Copyright (c) Pan Africa News. 
Origins of Human Nature (AS-HOPE), and International Training Program (ITP-HOPE), Japan Society for the Promotion of Science.

\section{REFERENCES}

Hernandez-Aguilar A 2006. Ecological and Nesting Patterns of Chimpanzees (Pan troglodytes) in Issa, Ugalla, Western Tanzania. Ph.D. thesis, University of Southern California.

Inoue E, Tashiro Y, Ogawa H, Inoue-Murayama M, Nishida T, Takenaka O 2013. Gene flow and genetic diversity of chimpanzee populations in East Africa. Primate Conserv 26:67-74.

Kano T 1972. Distribution and adaptation of the chimpanzee on the eastern shore of Lake Tanganyika. Kyoto Univ Afr Stud 7:37-129.

Moyer D, Plumptre AJ, Pintea L, Hernandez-Aguilar A, Moore J, Stewart F, Davenport TRB, Piel A, Kamenya S, Mugabe H, Mpunga N, Mwangoka M 2006. Surveys of Chimpanzees and Other Biodiversity in Western Tanzania. Unpublished report. Arlington, VA: United States Fish and Wildlife Service (USFWS).

Ndimuligo SA 2008. Assessment of Chimpanzee (Pan troglodytes) Population and Habitat in Kwitanga Forest, Western Tanzania. Master's dissertation, University of Witwatersrand, Johannesburg.

Ogawa H, Kanamori M, Mukeni SH 1997. The discovery of chimpanzees in the Loasi River area, Tanzania: A new southern distribution limit. Pan Afr News 4:1-3.

Ogawa H, Moore J, Kanamori M, Kamenya S 2004. Report on the chimpanzees of the Wansisi and Makomayo areas, Tanzania. Pan Afr News 11:3-5.

Ogawa H, Moore J, Kamenya S 2006a. Chimpanzees in the Ntakata and Kakungu areas, Tanzania. Primate Conserv 21:97-101.

Ogawa H, Sakamaki T, Idani G 2006b. The influence of Congolese refugees on chimpanzees in the Lilanshimba area, Tanzania. Pan Afr News 13:21-22.

Ogawa H, Idani G, Moore J, Pintea L, Hernandez-Aguilar A 2007. Sleeping parties and nest distribution of chimpanzees in the savanna woodland area, Ugalla, Tanzania. Int $J$ Primatol 28:1397-1412.

Plumptre AJ, Rose R, Nangendo G, Williamson EA, Didier K, Hart J, Mulindahabi F, Hicks C, Griffin B, Ogawa H, Nixon S, Pintea L, Vosper A, McLennan M, Amsini F, McNeilage A, Makana JR, Kanamori M, Hernandez-Aguilar A, Piel A, Stewart F, Moore J, Zamma K, Nakamura M, Kamenya S, Idani G, Sakamaki T, Yoshikawa M, Greer D, Tranquilli S, Beyers R, Hashimoto C, Furuichi T, Bennett E 2010. Eastern Chimpanzee (Pan troglodytes schweinfurthii): Status Survey and Conservation Action Plan 2010-2020. ISBN978-2-8317-1246-8. IUCN, Gland, Switzerland.

Yoshikawa M, Ogawa H, Sakamaki T, Idani G 2008. Population density of chimpanzees in Tanzania. Pan Afr News 15:17-20.

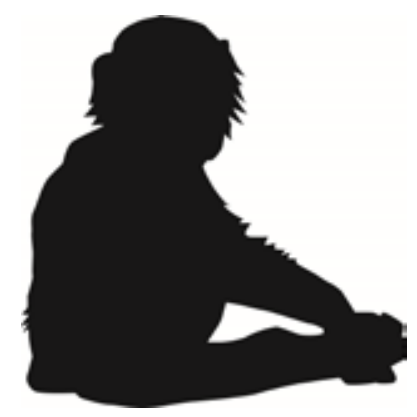

\section{<NOTE>}

\section{Well Digging by Semliki Chimpanzees: New Data on Laterality and Possible Significance of Hydrology}

\author{
William C. McGrew ${ }^{l}$, Linda F. \\ Marchant ${ }^{2}$, Charlotte L.R. Payne ${ }^{1}$, \\ Timothy H. Webster ${ }^{3} \&$ Kevin D. \\ Hunt ${ }^{4}$ \\ 1 Dept. of Archaeology \& Anthropology, University of \\ Cambridge, UK \\ 2 Dept. of Anthropology, Miami University, USA \\ 3 Dept. of Anthropology, Yale University, USA \\ 4 Dept. of Anthropology, Indiana University, USA \\ (E-mail:wcm21@cam.ac.uk)
}

\section{INTRODUCTION}

The wild chimpanzees (Pan troglodytes schweinfurthii) of Toro-Semliki Wildlife Reserve, Uganda, are the only population of wild apes yet reported to dig wells for drinking water. ${ }^{1}$ They dig holes by hand in sandy riverbeds, then drink the water collected there by mouth or with 'sponges' made of leaves. We previously reported that the excavated tailings of this digging were often 'bilobed' in distribution on the substrate, that is, clearly divided into separate piles of sand to the left and right sides of the hole (McGrew et al. 2007). Because these piles were symmetrical in volume, we inferred that the chimpanzees were manually ambilateral, that is, that they did not favour one hand or the other in digging. That is, we inferred that had their digging been right-biassed, then the rightside pile of sand would have been bigger.

However, our first report was no more than a pilot study, as it was done with only 2 days (July) of intensive etho-archaeological data collection over less than $1 \mathrm{~km}$ of riverbed, only in the dry season. Furthermore, it was done with only a single measure, 'volume'. Here we report a longer study done over 6 months (May-Nov.) over more than $5 \mathrm{~km}$ of riverbed, done in both wet and dry seasons. The aim of the follow-up study was to replicate and extend the pilot study's findings, but in the process several unexpected factors were revealed, chiefly hydrological ones.

In the first study in 2006, flow of surface water in the bed of the Mugiri River had ceased, leaving only scattered, stagnant pools. In some places, the sandy substrate was still moist, but in others it was dry. In the second study in 2008, surface water flow never ceased, though it varied in depth and volume, and the sand in the riverbed was always moist. Thus, environmental affordance of drinking water for the chimpanzees showed marked interannual variation.

With regard to laterality, we expected (as in the pilot study) that if the chimpanzees were manually biased at population-level to one side or another, then overall either left or right piles of tailings (lobes) would be larger. If there was no bias in the pooled data, then we expected no difference in any left- versus right-side measurements. 


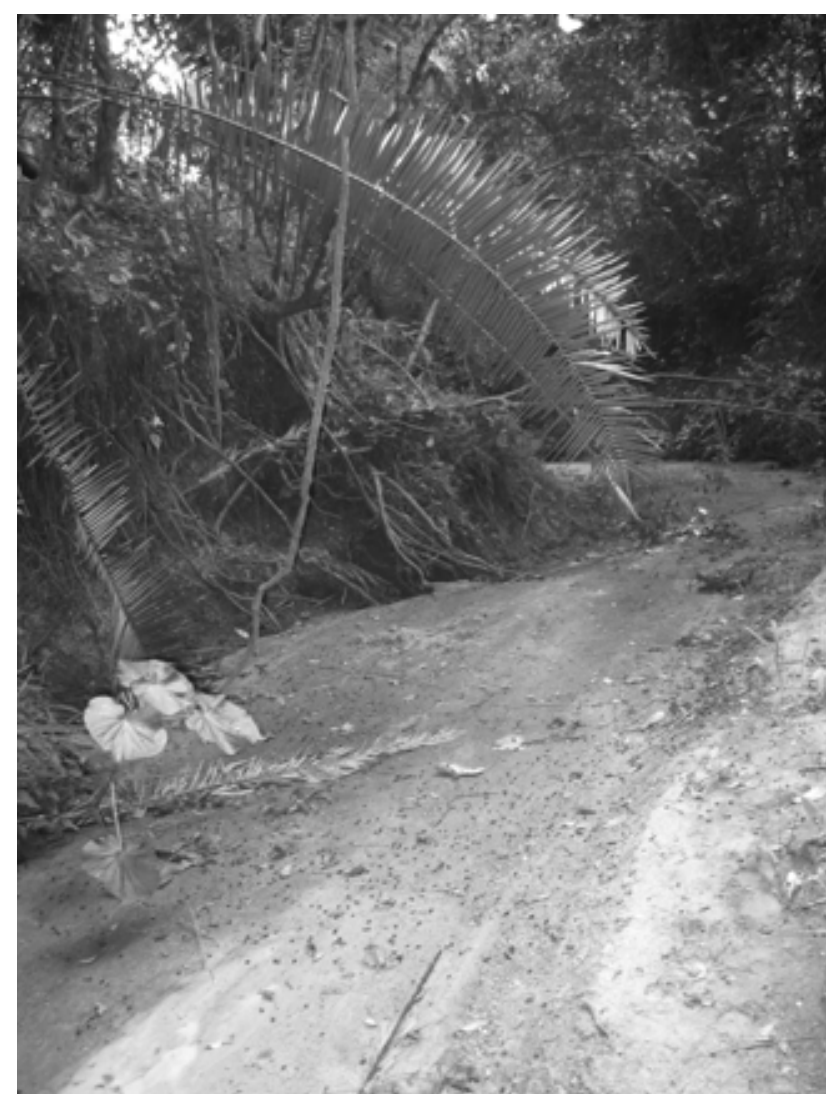

Figure 1. Dry Mugiri riverbed in 2006.

\section{METHODS}

Full details of the study site and methods are given elsewhere (Hunt 2000; Hunt \& McGrew 2002).

We found 121 wells, but 67 were either too disturbed by trampling to provide data or had a single, central tailing of excavated sand, so they could not provide data on laterality. For the remaining 54 wells that were bi-lobed (that is, had distinct left and right tailings), we recorded by tape measure $(\mathrm{cm})$ the following variables: well length, width and depth; length, width and depth of water in well (if present); mean distance to nearest running water; mean distance to nearest well (if present within 5 $\mathrm{m})$; presence/absence of leaf sponges. For each lobe, we recorded: length, wide, height (which multiplied gave

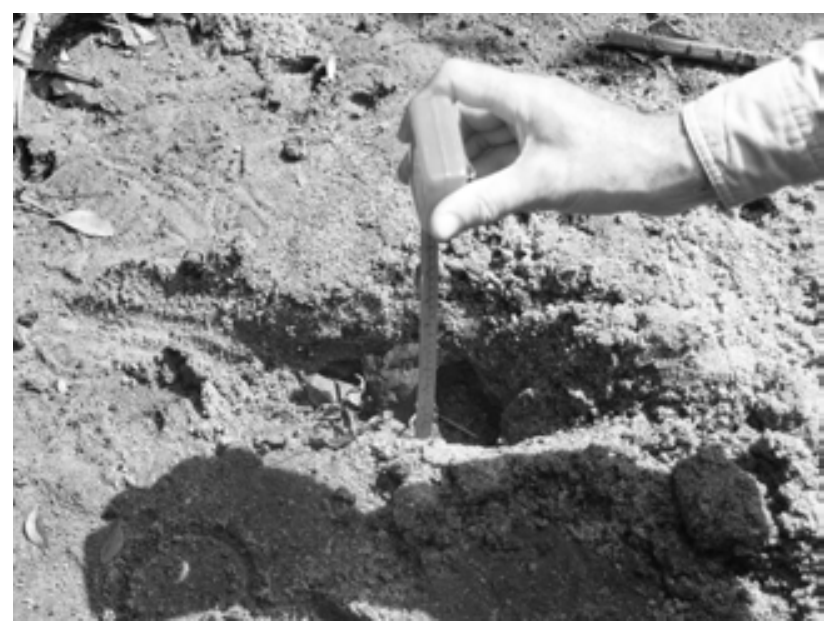

Figure 3. Measurement of water depth in well containing leaf 'sponge'.

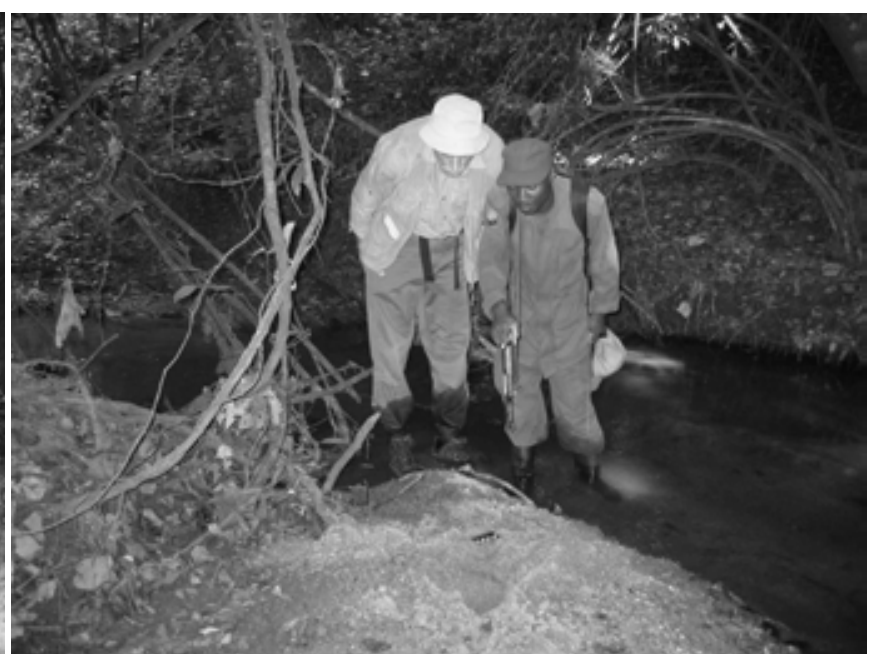

Figure 2. Mugiri riverbed in 2008. Two researchers examine well on sandbar, with flowing water behind.

volume); weight (nearest $100 \mathrm{~g}$, by spring balance). All variables except weight were for replication of 2006 data. Note that no data could be assigned to individuals, so data were pooled, which is usual practice for artefacts in archaeology.

\section{RESULTS}

Despite intensive searching and monitoring over a 5-fold longer distance of riverbed and over a 6-fold longer period in 2008, we found wells at a much lower rate and had no direct observations of well digging. Thus, the study remained archaeological, that is, based on indirect evidence.

Table 1 compares left $v s$. right lobes of bi-lobed tailings left at wells. As in 2006, there was no difference in 2008 in volume between them. Similarly, the new variable, weight, also showed no difference between left $v s$. right. Table 2 shows the extent of contrast between volumes of left and right lobes, that is, the ratio of $\mathrm{R} / \mathrm{L}$ when right lobes were bigger $v s$. L/R when left lobes were bigger. In both 2006 and 2008, there was no difference between these ratios.

Table 1. Left vs. right 'lobes' of excavated sand tailings of wells compared by volume for two years; weight of lobed tailings only for 2008.

\begin{tabular}{cccccccc}
\hline Year & $\begin{array}{c}\text { N of } \\
\text { wells }\end{array}$ & \multicolumn{3}{c}{ Mean volume $\left(\mathbf{c m}^{\mathbf{3}}\right)$} & \multicolumn{3}{c}{ Mean weight (g) } \\
\hline & & L lobe & R lobe & $\boldsymbol{p}$ & L lobe & R lobe & $\boldsymbol{p}$ \\
\cline { 2 - 7 } 2006 & 25 & 10,679 & 11,759 & NS & NA & NA & NA \\
2008 & 54 & 7,030 & 5,854 & NS & 2,295 & 2,128 & NS \\
\hline L $v s$. R $=$ Sign Test, two-tailed, NS = not significant; NA = not available
\end{tabular}

Table 2. Extent to which volumes of left vs. right tailings (lobes) (R/L, L/R) differ, for two years.

\begin{tabular}{cccccc}
\hline & \multirow{2}{*}{$\begin{array}{c}\text { N of } \\
\text { Year }\end{array}$} & \multicolumn{4}{c}{ Dominant Lobe } \\
\cline { 3 - 6 } & wells & Mean L/R & $\boldsymbol{p}$ & Mean R/L & $\boldsymbol{p}$ \\
\hline 2006 & 25 & 1.92 & $\mathrm{NS}$ & 2.22 & NS \\
& & $(n=31)$ & & $(n=23)$ & \\
2008 & 54 & 2.00 & NS & 1.68 & NS \\
\hline
\end{tabular}

L vs. R: Mann-Whitney U, two-tailed, NS = not significant


Table 3. Presence or absence of leafsponge tools at well, comparing two years.

\begin{tabular}{cccc}
\hline & \multicolumn{4}{c}{ Well } \\
\cline { 2 - 4 } Year & Tool & No Tool & Total \\
\hline 2006 & 11 & 80 & 91 \\
2008 & 1 & 120 & 121 \\
\hline
\end{tabular}

Table 4. Relationship between rainfall $(\mathrm{mm})$ and abundance of wells: Month-by-month comparison of 2008 versus 1997-2006 (median).

\begin{tabular}{lcccccccc}
\hline & \multicolumn{7}{c}{ Rainfall (mm) } \\
\cline { 2 - 9 } Year(s) & May & June & July & Aug & Sep & Oct & Nov & Total \\
\hline $1997-2006$ & 164 & 55 & 73 & 141 & 94 & 149 & 168 & 844 \\
2008 & $(73)$ & 98 & 180 & 50 & 86 & 210 & $(182)$ & 879 \\
Wells found 2008 & 0 & 29 & 25 & 48 & 19 & 0 & 0 & 121 \\
\hline $\begin{array}{l}\text { Spearman's } r h o, r_{s}=-0.46, \text { two-tailed, NS } \\
()=\text { extrapolated figure based on partial data only }\end{array}$
\end{tabular}

However, there were differences between years: Table 1 shows that wells were smaller in 2008: Volume of both left and right lobes was less. Table 3 shows that in 2008, only one leaf sponge tool was found at 121 wells, while in 2006 , one or more sponge tools were found on average at every ninth well.

\section{DISCUSSION}

The symmetry between left and right lobes was replicated across study years, adding more data to the long list of studies that have failed to find handedness in wild chimpanzees (e.g. Marchant \& McGrew 2013).

However, the unexpected inter-annual differences found require explanation. Overall rainfall seems not to suffice: Table 4 compares monthly rainfall totals over the study period in 2008 with average totals for a previous 10 yr period (1997-2006). Overall, 2008 was not an atypical year, although July was very wet $(180 \mathrm{~mm})$ and August very dry $(50 \mathrm{~mm})$. There was no correlation between monthly rainfall and abundance of wells.

Instead, the contrast may reflect hydrological differences, that is, the level of the water table in the riverbed. A high water table allows for shallower wells and so, less sand needs to be removed, while a low water table requires deeper wells and the removal of more sand. Similarly, water can be drunk directly with the lips from a shallow well, while sponge use facilitates drinking from a deeper well.

Such hydrological factors rarely, if ever, have been addressed in field studies of wild chimpanzees, but they may be crucial for explaining the presence or absence of potable drinking water in hot, dry and open habitats, especially in the dry season. Further study is needed.

\section{ACKNOWLEDGEMENTS}

We thank: Uganda Wildlife Authority and Uganda Council for Science and Technology for permission to do research at Semliki; UWA rangers for field assistance and Semliki camp staff for domestic assistance; Phineas Hodson and Samantha

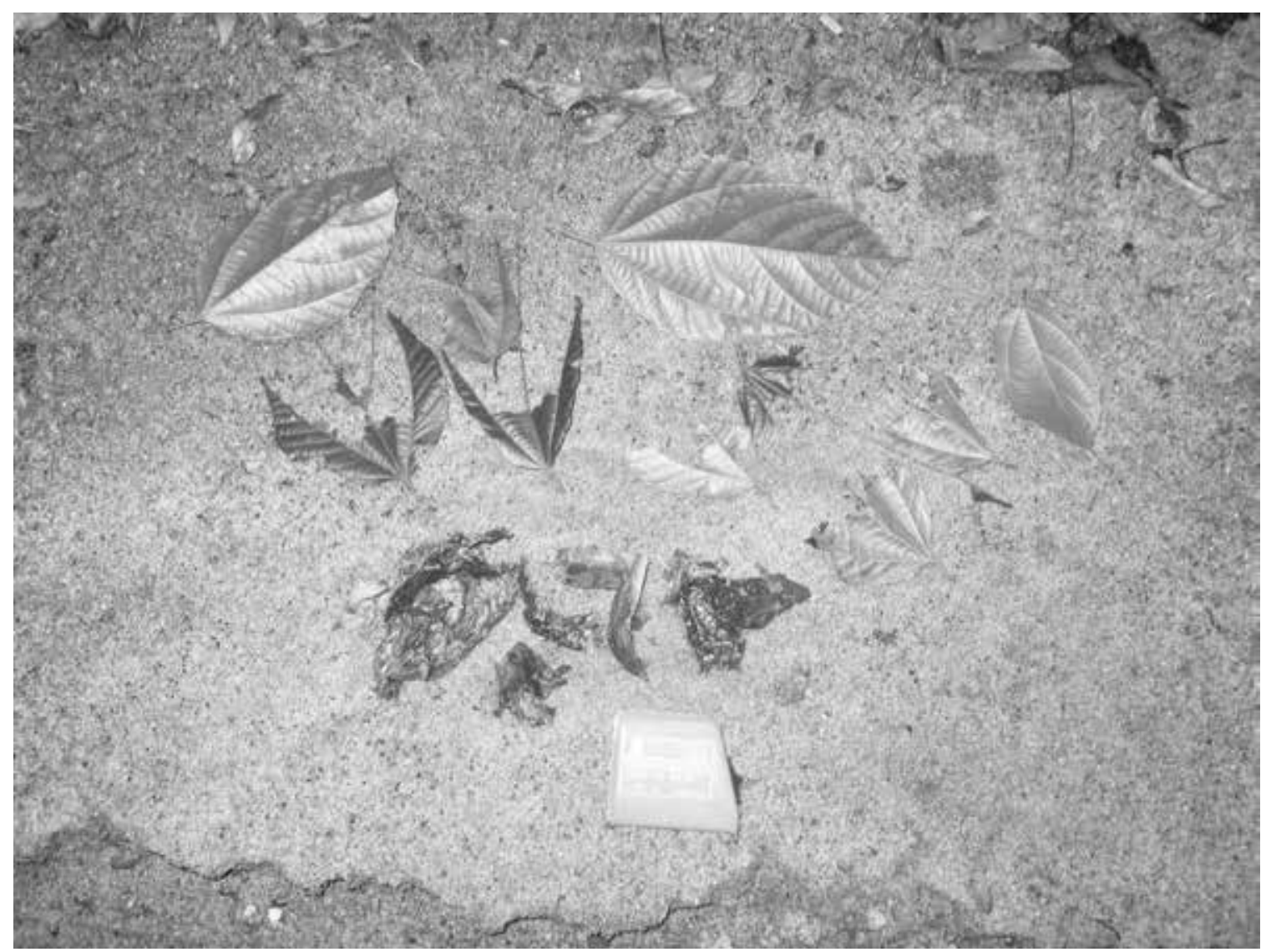

Figure 4. Leaf 'sponges' for extracting water from wells. Top row: Intact leaves plucked from source. Middle row: Processed leaves with softer tissue removed and used but stiff veins discarded. Bottom row: Used sponges. 
Russak for research collaboration; Rebecca Jeanne Andrew Memorial Fund, Miami University (THW) for funding for field work; Leverhulme Trust (WCM) for funding for analysis and writing up results.

\section{Notes}

1. Another population of chimpanzee (Pan troglodytes verus) in southeastern Senegal has been reported to dig wells (GalatLuong \& Galat 2000; Galat-Luong et al. 2009). The authors reported that apes used tools to dig their wells, but baboons as well as chimpanzees were said to dig wells, and no criteria were presented for distinguishing between the two species wells. The first report is an abstract, and the second was published in a non-peer-reviewed journal. Neither presented any systematic or quantitative data, nor observations of behaviour, so these claims must be taken as tentative until documentation is provided.

\section{REFERENCES}

Galat-Luong A, Galat G 2000. Chimpanzees and baboons drink filtrated water. Folia Primatol 71:258 (abstract).

Galat-Luong A, Galat G, Nizinski G 2009. Une consequence du rechauffement climatique: les chimpanzes filtrent leur eau de boisson. Geographia Technica. Numéro spécial, 2009:199-204.

Hunt KD 2000. Initiation of a new chimpanzee study site at Semliki-Toro Wildlife Reserve, Uganda. Pan Afr News 7:14-17.

Hunt KD, McGrew WC 2002. Chimpanzees in the dry habitats of Assirik, Senegal, and Semliki Wildlife Reserve, Uganda. In: Boesch C, Hohmann G, Marchant LF (eds) Behavioural Diversity in Chimpanzees and Bonobos. Cambridge University Press, Cambridge, pp. 35-51.

Marchant LF, McGrew WC 2013. Handedness is more than laterality: lessons from chimpanzees. Ann NY Acad Sci 1288:1-8.

McGrew WC, Marchant LF, Hunt KD 2007. Ethoarchaeology of manual laterality: well digging by wild chimpanzees. Folia Primatol 78:240-244.

\section{<NOTE> \\ Newly Observed Bird Consumption by a Chimpanzee (Pan troglodytes) at Bossou, Guinea, West Africa}

\author{
Lira Yu ${ }^{1,2}$, Boniface Zogbila ${ }^{3}$ \& \\ Tetsuro Matsuzawa \\ 1 Primate Research Institute, Kyoto University, Japan \\ 2 Japan Society for the Promotion of Science \\ 3 Institut de Recherche Environmentale de Bossou \\ (E-mail:yu.lira.87z@st.kyoto-u.ac.jp)
}

\section{INTRODUCTION}

Bossou chimpanzees have shown low rates of meat consumption compared to other communities (Sugiyama \& Koman 1987; Hockings et al. 2012). Therefore, the addition of data describing their prey repertoire is imperative for ecological and behavioral studies at this site. Here, we report a novel observation of bird consumption by one adult female chimpanzee in the Bossou community.

\section{METHODS}

Behavioral observations were conducted at Bossou, one of the long-term research sites for chimpanzees located at the south-east corner of the Republic of Guinea, West Africa (Matsuzawa et al. 2011). The core area used by Bossou chimpanzees includes approximately $6 \mathrm{~km}^{2}$, dominated by primary and secondary forest and surrounded by cultivated or abandoned fields and shrub forest. Consumption of the wild bird was observed by LY and $\mathrm{BZ}$, who recorded all behavioral occurrences during the event ad libitum.

\section{OBSERVATION}

On October 30, 2012, at 7:39 AM, we (LY and BZ) observed four adult chimpanzees (JJ, TA, FF, and Jr) in the forest. At 7:47 AM, three adult male chimpanzees (JJ, TA, and FF) started to move. However an adult female chimpanzee $\mathrm{Jr}$ (estimated to be 54 years old) remained. For approximately ten minutes, Jr showed no movement. At 7:57 AM, shrubs began to rustle. We heard a typical call of coucal (a bird belongs to cuckoo family) from a nearby bush. The call consists of a series of 'hoos' which at first increase in rate and volume and die away at the end (Serle et al. 1990). A few seconds later, Jr suddenly moved toward the bush. We saw Jr capturing two nestlings at once from a nest that had been constructed in the bush and located ca. 2 meters above the ground. Jr walked a few steps away holding the two nestlings one in each hand and sat on the ground. Jr started to take a bite of the nestling in her left-hand. Then Jr put the remainder of the nestling on the ground and consumed a few leaves from a nearby liana. We (BZ and TM) later identified the leaves as Clerodendrum silvanum. This liana is characterized by its needle-like spines that are derived from young stems and petioles but not on epidermis (Hawthorne \& Jongkind 2006). For the next few minutes, the nestling and leaves were consumed in an alternating manner. Only the lefthand was used during consumption of both items, while the right-hand continued to hold the other nestling. At 8:07 AM, Jr stopped eating and put what remained of the consumed nestling on the ground. Jr stood up bipedally, moved a few steps and started slapping the other nestling on the ground. The nestling emitted some vocalizations when it hit on the ground. In response, Jr released the nestling from her hand and stepped back. Soon, Jr took the nestling again and continued to slap it on the ground. After several cycles of slapping and stepping away from the nestling, Jr picked the nestling up and moved out of sight.

At 9:09 AM, after we lost track of Jr, we returned to the bush and discovered a bird carcass on the ground amid scattered leaves that had been consumed (see Figure 1). We assumed this carcass was the first nestling that $\mathrm{Jr}$ consumed because it lacked some body parts; its head and legs were missing from the carcass while most of the body trunk remained intact. We could not find any detached body parts in the vicinity of the carcass, suggesting that these had all been consumed by Jr. Because of the emitted call and the carcass, it was identified as the black-throated 